10IKC-293

\title{
MINERALOGY AND PETROLOGY OF THE SALITRE I PHOSCORITE-CARBONATITE-ALKALINE COMPLEX, BRAZIL
}

\author{
Barbosa* ESR ${ }^{1,2}$, Brod JA ${ }^{1,2,3}$, Junqueira-Brod TC ${ }^{1,3}$, Cordeiro PFO ${ }^{2,3}$, Santos RV ${ }^{2,3}$, Dantas EL ${ }^{2,3}$ \\ 1-Instituto de Estudos Sócio-Ambientais, Universidade Federal de Goiás, Goiânia, Brazil, elisa.barbosa@uol.com.br \\ 2-Instituto de Geociências, Universidade de Brasília, Brasília, Brazil \\ 3-Conselho Nacional de Desenvolvimento Cientifico e Tecnológico, Brasília, Brazil
}

\section{INTRODUCTION}

Alkaline-carbonatite complexes are a subject of petrologic and metallogenetic interest due to the large variety and complexity of the magmatic processes involved in their formation. This work uses mineral chemistry, whole-rock geochemistry, stable $(\mathrm{C}, \mathrm{O})$ and radiogenic $(\mathrm{Sr}, \mathrm{Nd})$ isotope data of carbonatites from the Salitre alkaline-phoscoritecarbonatite complex, and additional results from associated bebedourite (Barbosa et al., 2008) and phoscorite (Barbosa et al. 2012) to investigate their petrogenesis and develop an integrated evolution model for the complex.

The Late-Cretaceous Salitre I complex, in the Alto Paranaíba Igneous Province, central Brazil, has a distorted oval shape, and is composed of multiple intrusions. Bebedourites are the dominant rock-type, intruded by swarms of carbonatite and phoscorite ring dykes. Perovskite bebedourites (B1) with swarms of ring dykes of carbonatites and phoscorites (P1 and P2) dominate the central and northern part of the complex whereas the southern portion is occupied by melanite bebedourites (B2). Syenite dykes (S1) are also present. Salitre II and III are bebedourite-dominated smaller intrusions, respectively to the north and to the south of Salitre I.

\section{PETROGRAPHY}

Salitre carbonatites vary from white to gray, fine- to coarsegrained. They occur mainly as centimetric veins to metric dykes, and, alternatively, as layers. Magmatic layering is observed in larger bodies, where pure carbonatite grades into cumulates rich in magnetite, phlogopite, apatite, olivine and pyrochlore. Crystal mush layers are often deformed and ruptured by magmatic chamber movement (Fig. 1).

On the basis of field relationships, petrography, and major element and mineral chemistry Salitre carbonatites are divided into 5 units $-\mathrm{C} 1, \mathrm{C} 2, \mathrm{C} 3, \mathrm{C} 3 \mathrm{a}$ and $\mathrm{D} 4 . \mathrm{C} 1$ and $\mathrm{C} 2$ correspond to magnesiocarbonatites, C3 to calciocarbonatites, $\mathrm{C} 3 \mathrm{a}$ to nelsonitic cumulates, and D4 to late-stage magnesiocarbonatite dykes.

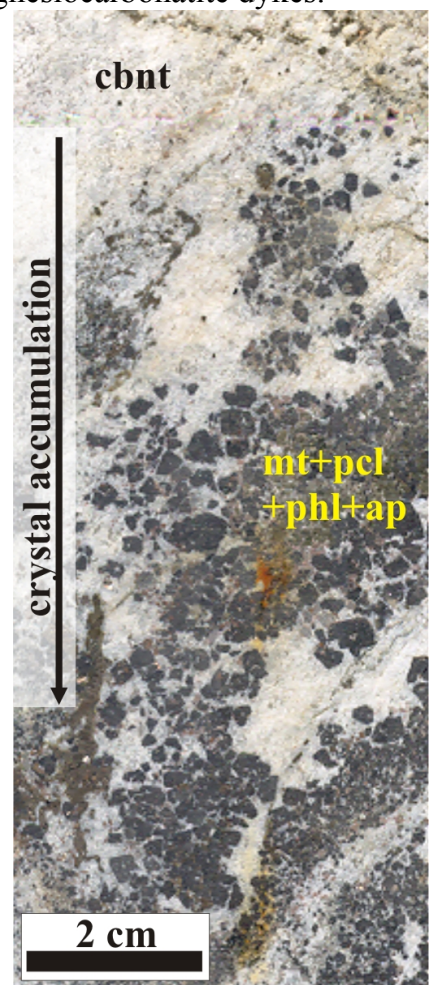

Figure 1 - Magnetite, apatite and subordinated pyrochlore accumulation, generating nelsonitic cumulate from carbonatite magma.

C1 magnesiocarbonatites are characterized by aluminous phlogopite, irregular aggregates of prismatic apatite, and rare olivine. $\mathrm{C} 2$ magnesiocarbonatites are composed almost entirely of carbonate. C3 carbonatites vary from olivine calciocarbonatite, through pyrochlore calciocarbonatite to nearly pure calciocarbonatite, and may produce cumulates rich in apatite, magnetite, and pyrochlore (C3a nelsonitic cumulates). Late-stage magnesiocarbonatites (D4) occur as fine-grained dykes. 


\section{$10^{\text {th }}$ International Kimberlite Conference, Bangalore - 2012}

\section{MINERAL CHEMISTRY}

The main mineral phases present in the Salitre carbonatites were analyzed by WDS using a CAMECA SX 50 electron microprobe at the University of Brasília, operating at $15 \mathrm{kV}$ and $20 \mathrm{nA}$.

Phlogopite from Salitre carbonatites varies from euhedral crystals, almost without pleochroism in C1 samples, trhough subhedral grains with tetra-ferriphlogopite rims, to aggregates of small anhedral "flakes" of pure tetraferriphlogopite in $\mathrm{C} 3$ and $\mathrm{C} 3 \mathrm{a}$. Figure $2 \mathrm{a}$ shows the compositional range of phlogopite from Salitre carbonatites.

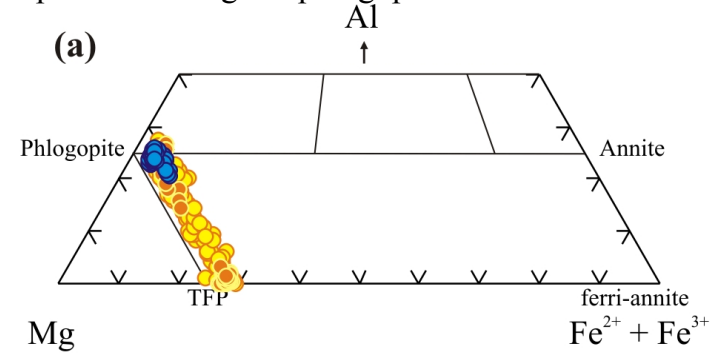

(b)

$\mathrm{Al}$

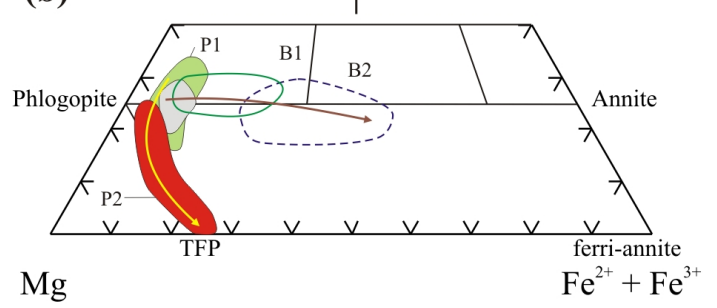

KEY:

- $\mathrm{C} 1$ magnesiocarbonatites $\bigcirc \mathrm{C} 3$ calciocarbonatites $-\mathrm{C} 3 a$ nelsonitic cumulates

$\subseteq$ B1a olivine bebedourites $\square$ B1b perovskite bebedourites ‘ $=-$ B2, B2a and B2b titanite $\subseteq$ P1 phoscorites

P2 phoscorites melanite bebedourites

Figure 2 - Classification of the analysed phlogopites in the system Mg-AlFe: a) compositional ranges for Salitre carbonatites; b) compositional phlogopite fields of other Salitre complex units (bebedourites and phoscorites).

The $\mathrm{Al}$ content in phlogopite is an important marker of carbonatite evolution (e.g. Brod et al., 2001, Lee et al., 2003), because it occurs in low concentration in carbonatitic magma, and tends to be rapidly consumed with the crystallization of phlogopite. Moreover, in a silicatecarbonatitic liquid immiscibility event, Al will be strongly partitioned to the silicate liquid (e.g. Le Bas, 1989), generating an abrupt Al depletion in the carbonate-rich counterpart. Both processes lead to tetra-ferriphlogopite crystallization, but gradual composition variation is expected in the case of crystal fractionation, whereas liquid immiscibility results in abrupt changes. The highest Al content occurs in phlogopites from C1. Phlogopites from C3 and C3a span the complete phlogopite - tetraferriphlogopite series (PHL-TFP, Fig. 2a). Figure 2b shows the observed trends in other Salitre petrogenetic series. In bebedourites (Barbosa et al., 2008), phlogopite evolves along the phlogopite-annite series in the sequence olivine bebedourites (B1a) - perovskite bebedourites (B1b) titanite-melanite bebedourites (B2, B2a and B2b). In the early P1 phoscorites (Barbosa et al., 2012), phlogopite compositions are restricted to the beginning of PHL-TFP serieswhereas P2 covers all PHL-TFP series range.

Only two carbonatite groups contain olivine - $\mathrm{C} 1$ magnesiocarbonatites and $\mathrm{C} 3$ calciocarbonatites. Olivine is rare in $\mathrm{C} 1$, but common in $\mathrm{C} 3$, and presents wide textural variety, from euhedral zoned grains to small anhedral crystals. Olivine composition range from Salitre carbonatites is restricted to forsterite. The olivine from $\mathrm{C} 1$ magnesiocarbonatites has the higher Fo contents. Figure 3 compares the Fo content in carbonatite olivine with those in olivine from other associated rock types in the Salitre complex, such as olivine bearing- bebedourites (B1a) and phoscorites (P1 and P2). Curiously, olivine in the least evolved rocks (bebedourites) has the lowest Fo contents. The forsterite molecule increases in phoscorite olivine, reaching the highest contents in the olivine from carbonatites. This is consistent with data from Phalaborwa (Eriksson, 1989) and Sokli (Lee et al., 2004). Olivine from Salitre carbonatites contains very low $\mathrm{NiO}$ and $\mathrm{Cr}_{2} \mathrm{O}_{3}$, and significant amounts of $\mathrm{TiO}_{2}$, as observed in olivine from other phoscorites and carbonatites (e.g Eriksson, 1989, Krasnova et al., 2004 and Chakhmouradian \& Zaitsev, 2004). Significant compositional variation occurs in $\mathrm{CaO}$ and $\mathrm{MnO}$, whereby olivines from $\mathrm{C} 1$ has lower contents in these elements compared with $\mathrm{C} 3$.

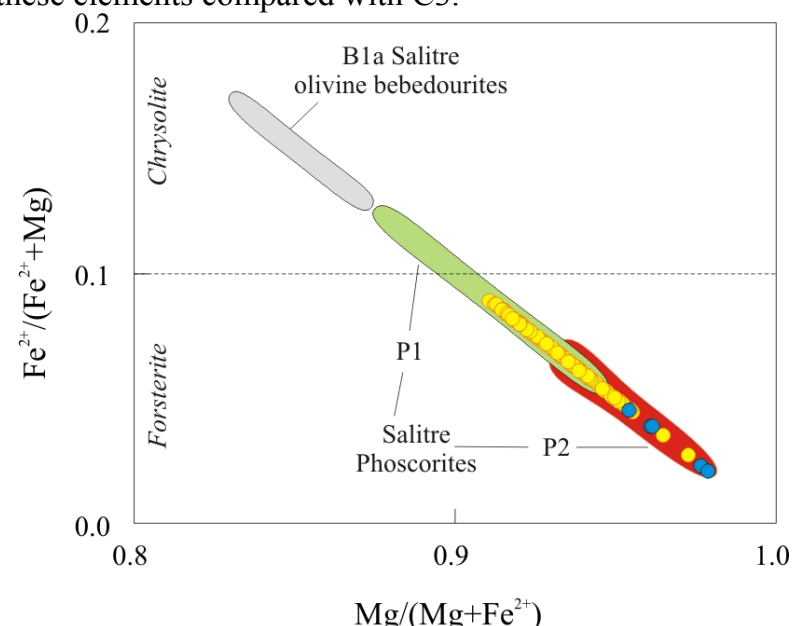

Figure 3 - Olivine compositional range for Salitre carbonatites, compared with olivines from Salitre bebedourites (B1a) and phoscorites (P1 and P2). Symbols as in Fig. 2.

Magnetite occurs in Salitre carbonatites in variable modal proportions - from magnetite-free samples to rocks where magnetite is an essential constituent, such as nelsonitic carbonatites (C3a). The compositional range of Salitre magnetites is simillar to that observed in Salitre phoscorites (Barbosa et al., 2012), restricted to the ideal end-member of 


\section{$10^{\text {th }}$ International Kimberlite Conference, Bangalore - 2012}

ulvospinel-magnetite series, with little proportion of magnesioferrite solid solution. The most important substitution involve $\mathrm{MgO}$ and $\mathrm{TiO}_{2}$, with little variation in $\mathrm{MnO}, \mathrm{Al}_{2} \mathrm{O}_{3}, \mathrm{NiO}, \mathrm{Cr}_{2} \mathrm{O}_{3}, \mathrm{ZnO}$ and $\mathrm{V}_{2} \mathrm{O}_{5}$. Lee et al. (2004, 2005) report $\mathrm{TiO}_{2}$ and $\mathrm{MgO}$ decrease with the phoscorites and carbonatites evolution in the Sokli complex. The same relationships were observed by Brod et al. (2005) in the sequence phlogopite picrites - bebedourites - carbonatites from Tapira complex (APIP), and by Reguir et al. (2008) in carbonatites from Kerimasi (Tanzania). In the Salitre complex, $\mathrm{TiO}_{2}$ and $\mathrm{MgO}$ in magnetite decrease with the evolution of bebedourites in the B1a-B1b-B2 direction. Phoscorite magnetites show simillar behavior, with lower $\mathrm{TiO}_{2}$ and higher $\mathrm{MgO}$ concentration. Magnetites from B2 bebedourites and $\mathrm{C} 1$ magnesiocarbonatites has very distinct trends, though they converge to the same magnetite endmember. It is possible that these two rock types derived from a liquid immiscibility event, where $\mathrm{TiO}_{2}$ was preferably partitioned to the silicate portion (bebedouritic), and $\mathrm{MgO}$ was enriched in the carbonatite counterpart. $\mathrm{C} 3$ and $\mathrm{C} 3$ a magnetites have a simillar behavior, with core-rim relationships indicating that $\mathrm{TiO}_{2}$ decreases with the decreasing of $\mathrm{MgO}$ in calciocarbonattites, similarly to other Salitre petrogenetic series (bebedourites and phoscorites).

Pyrochlore may be an acessory phase in late-stage evolution of carbonatite complexes (e.g. Hogarth, 1989; Lee et al., 2004). In Salitre, pyrochlore occurs in the main carbonatite groups $\mathrm{C} 1, \mathrm{C} 2, \mathrm{C} 3$ and $\mathrm{C} 3 \mathrm{a}$. In the early stage of evolution, it forms euhedral crystals in equilibrium with olivine and aluminous phlogopite, and in late-stage carbonatites it varies from euhedral to anhedral, dark-red, orange to yellow grains. The analysed grains correspond dominantly to the pyrochlore sub-group (Fig.4). They are characterized by moderate $\mathrm{TiO}_{2}$ and low $\mathrm{Ta}_{2} \mathrm{O}_{5}$ contents. Ba-rich pyrochlore occurs only as irregular cores in some $\mathrm{C} 1$ crystals, suggesting that bariopyrochlore may form in the early-stage magmatic evolution of magnesiocarbonatites, as well as by weathering alteration (e.g. Lumpkin \& Ewing, 1995). Figure 4 also shows important compositional differences between pyrochlores from Salitre phoscorites and carbonatites. When compared with carbonatites, pyrochlores from $\mathrm{P} 2$ phoscorites (Barbosa et al., 2012) have higher $\mathrm{Ta}_{2} \mathrm{O}_{5}, \mathrm{UO}_{2}, \mathrm{ThO}_{2}, \mathrm{ZrO}_{2}$ and $\mathrm{FeO}$ contents.

\section{WHOLE-ROCK TRACE ELEMENTS}

Different Salitre carbonatite groups show simillar compositions, with the obvious exception of $\mathrm{MgO}$ and $\mathrm{CaO}$, which discriminate magnesiocarbonatites from calciocarbonatites. Salitre carbonatites have low $\mathrm{SiO}_{2}$, $\mathrm{Na}_{2} \mathrm{O}, \mathrm{K}_{2} \mathrm{O}, \mathrm{Al}_{2} \mathrm{O}_{3}$ and $\mathrm{TiO}_{2}$ contents. C3a nelsonitic cumulates are exceptions, and may contain variable $\mathrm{P}_{2} \mathrm{O}_{5}$, and. $\mathrm{Fe}_{2} \mathrm{O}_{3}(\mathrm{t})$, related to the strong presence of apatite and magnetite.

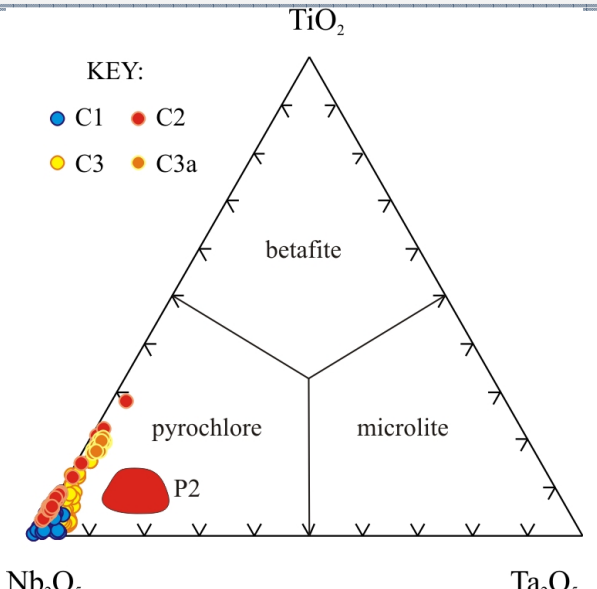

Figure 4 - Triangular $\mathrm{Nb}$-Ti-Ta pyrochlore classification scheme (Hogarth, 1977), for pyrochlores from carbonatites. Composition of pyrochlores from P2 phoscorites are shown for comparison (red field).

Trace-element normalized diagrams of the Salitre carbonatites show negative spikes at $\mathrm{Rb}, \mathrm{K}$, and $\mathrm{Ti}$, and positive spikes at $\mathrm{Ba}$ and $\mathrm{Sr}$, besides a strong negative $\mathrm{P}$ anomaly. D4 magnesiocarbonatites are strongly enriched in $\mathrm{Ba}$. The increase in the negative $\mathrm{P}$ anomaly, may be either associated with the removal of apatite from the system by crystal fractionation, or with a possible carbonate-phosphate liquid immiscibility event.

Chondrite-normalized diagrams show strong LREE/HREE fractionation. Magnesiocarbonatites $\mathrm{C} 1$ and $\mathrm{C} 2$ are less enriched in REE than calciocarbonatites. D4 late-stage magnesiocarbonatites contain the widest variation, with two samples exhibiting strong LREE/HREE fractionation, while one sample shows a little fractionated pattern, uncommon for carbonatites. This feature probably corresponds to carbonate post-magmatic remobilization.

$\delta^{18} \mathrm{O}_{\mathrm{SMOW}}$ and $\delta^{13} \mathrm{C}_{\mathrm{PDB}}$ of all Salitre carbonatite samples span a relatively narrow range, within the field of primary carbonatites (Fig. 5).

\section{DISCUSSIONS AND CONCLUSIONS}

In summary, textural and compositional differences observed in phlogopite, magnetite, olivine and pyrochlore from $\mathrm{C} 1, \mathrm{C} 3$ and $\mathrm{C} 3 \mathrm{a}$ Salitre carbonatites indicate magmas at distinct evolution stages. $\mathrm{C} 1$ magnesiocarbonatites are related to the early stage, followed by $\mathrm{C} 2$ magnesiocarbonatites and $\mathrm{C} 3$ calciocarbonatites. $\mathrm{C} 1$ magnesiocarbonatites were generated by a silicatecarbonatitic liquid immiscibility, whereas $\mathrm{C} 2$ magnesiocarbonatites and C3 calciocarbonatites are products of carbonate-phosphate liquid immiscibility. C3a nelsonitic cumulates result from crystal fractionation that accumulates apatite, magnetite and pyrochlore from $\mathrm{C} 3$ magma. D4 magnesiocarbonatites are the most evolved carbonatite members of Salitre complex. 


\section{$10^{\text {th }}$ International Kimberlite Conference, Bangalore - 2012}

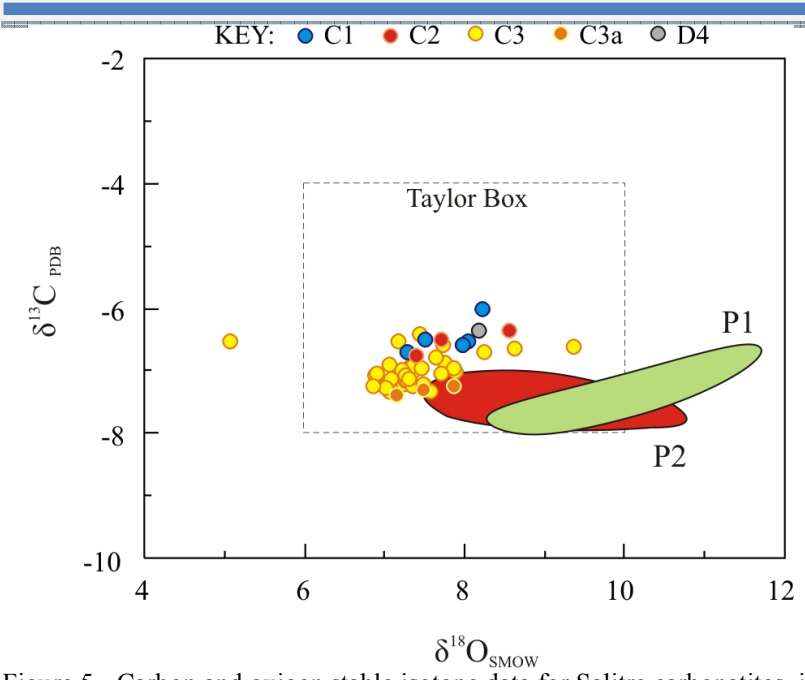

Figure 5 - Carbon and oxigen stable isotope data for Salitre carbonatites, in comparison with data from Salitre phoscorites (P1 and P2, Barbosa et al., 2012). Dashed field are isotopic composition of primary carbonatite (Taylor Box).

\section{DISCUSSIONS AND CONCLUSIONS}

In summary, textural and compositional differences observed in phlogopite, magnetite, olivine and pyrochlore from C1, C3 and C3a Salitre carbonatites indicate magmas at distinct evolution stages. $\mathrm{C} 1$ magnesiocarbonatites are related to the early stage, followed by $\mathrm{C} 2$ magnesiocarbonatites and $\mathrm{C} 3$ calciocarbonatites. $\mathrm{C} 1$ magnesiocarbonatites were generated by a silicatecarbonatitic liquid immiscibility, whereas $\mathrm{C} 2$ magnesiocarbonatites and $\mathrm{C} 3$ calciocarbonatites are products of carbonate-phosphate liquid immiscibility. C3a nelsonitic cumulates result from crystal fractionation that accumulates apatite, magnetite and pyrochlore from $\mathrm{C} 3$ magma. D4 magnesiocarbonatites are the most evolved carbonatite members of Salitre complex.

Mineral chemistry, whole-rock geochemistry, and isotopic composition of bebedourites, phoscorites, and carbonatites show that these rocks are related to each other through multiple events of fractional crystallization and liquid immiscibility. The parental magma for the Salitre complex probably had a composition similar to the phlogopite picrites that occur in all APIP carbonatite-bearing complexes. This primitive magma generated the olivine perovskite bebedourites (B1a) by crystal accumulation (Fig. 6 , stage 1). The removal of olivine and perovskite would drive the residual magma toward increased $\mathrm{P}_{2} \mathrm{O}_{5}$ e $\mathrm{CO}_{2}$, eventually resulting in the separation between a phoscorite (P1) and a silicate magma, the latter producing the olivinefree perovskite bebedourites (B1b, fig. 6, stage 2 ). The continuous build-up of volatiles in the silicate branch led to a second immiscibility event, producing the melanite bebedourites (B2) and magnesiocarbonatites (C1, fig. 6, stage 3 ). This carbonatite magma evolved by subdivision into "simpler" fractions (Panina \& Motorina, 2008): Mgrich (C2 magnesiocarbonatites), $\mathrm{P}$ - and Fe-rich (P2 phoscorites) and Ca-rich (C3 calciocarbonatites, fig. 6, stage 4). Late-stage, Ba-rich D4 magnesiocarbonatites are the residue of the fractionation of $\mathrm{C} 2$ magnesiocarbonatites, whereas the $\mathrm{C} 3$ calciocarbonatites are either the final product of the differentiation of $\mathrm{P} 2$ phoscorites, or evolve along a path parallel to them. C3 calciocarbonatites produced the $\mathrm{C} 3 \mathrm{a}$ nelsonitic cumulates through fractionation of magnetite, pyrochlore, and apatite. B2 melanite bebedourites evolved directly by fractional crystallization to the syenitic (S1) end members (fig. 6, stage 5).
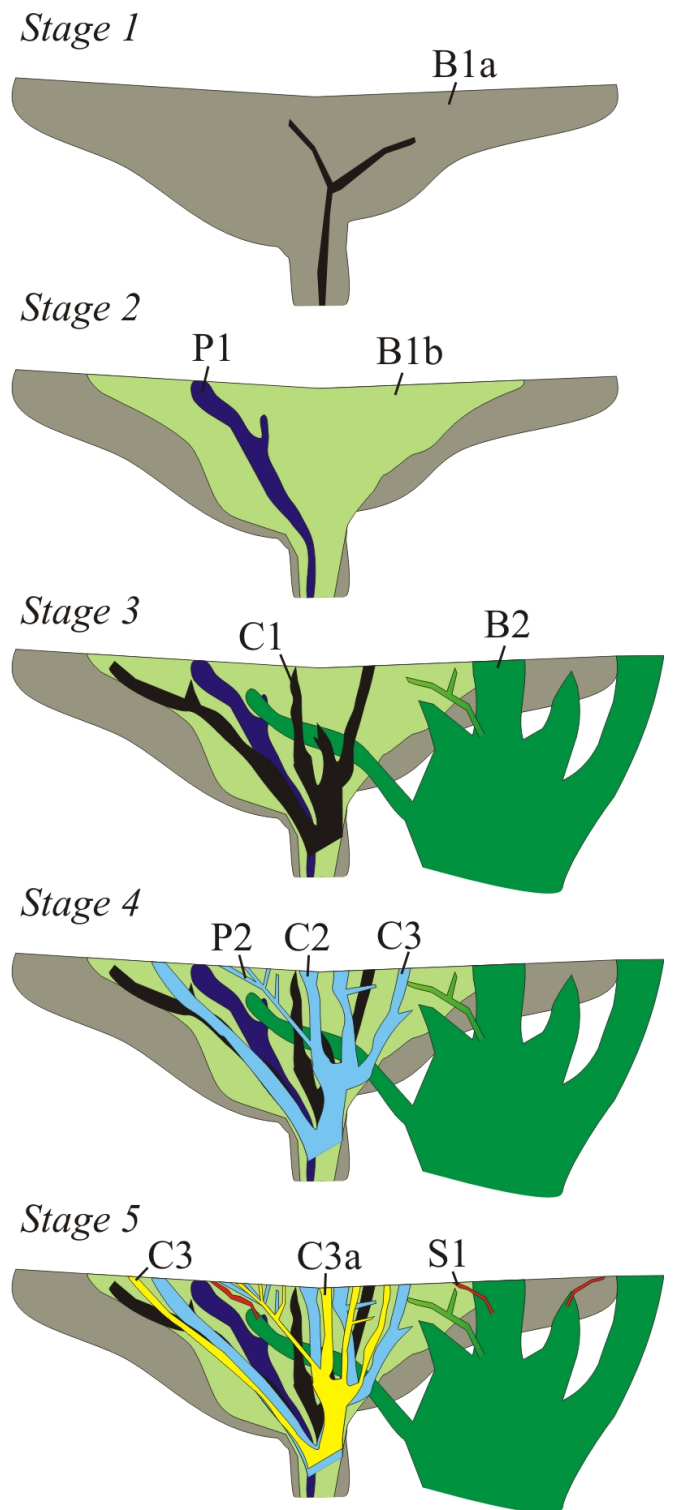

Figure 6 - Schematic outline of integrated evolution model for the Salitre complex. 


\section{$10^{\text {th }}$ International Kimberlite Conference, Bangalore - 2012}

\section{ACKNOWLEDGEMENTS}

This work was suported by $\mathrm{CNPq}$ (Brazilian Council for Research and Development) and University of Brasília.

\section{REFERENCES}

Barbosa, E.S.R., Junqueira-Brod, T. C., Brod, J. A., Dantas, E.L., 2008. Petrology of bebedourites from the Salitre phoscorite-carbonatite complex, Brazil. In: 9th International Kimberlite Conference, 2008, Frankfurt. Extended Abstracts. Frankfurt : COSIS - Copernicus Systems, 2008. p. 9IKC-A-00332.

Barbosa, ESR, Brod, JA, Junqueira-Brod, TC, Cordeiro, PFO, Santos, RV Dantas, EL. 2012. Phoscorites from the Salitre alkaline complex, Brazil: origin and petrogenetic implications. In: 10th International Kimberlite Conference, 2012, Bangalore. Extended Abstracts. Bangalore: p. 10IKC229.

Brod J.A., Gaspar J.C., Araújo D.P. Gibson S.A., Thompson R.N., Junqueira-Brod, T.C., 2001. Phlogopite and tetra-ferriphlogopite from Brazilian carbonatite complexes: petrogenetic constraints and implications for mineral-chemistry systematics. Journal of Asian Earth Sciences 19:265-296.

Brod J.A., Gaspar, J.C., Diniz-Pinto H. S., Junqueira-Brod T.C., 2005. Spinel chemistry and petrogenetic processes in the Tapira alkaline-carbonatite complex, Minas Gerais, Brazil. Revista Brasileira de Geociências 35 (1): 2332.Chakhmouradian \& Zaitsev, 2004

Eriksson, S.C., 1989. Phalaborwa: A saga of magmatism, metassomatism and miscibility. In: K. Bell (Editor) Carbonatites: genesis and evolution. Unwin Hyman, London, pp. 221-254.

Hogarth, D. D., 1977. Classification and nomenclature of the pyrochlore group. American Mineralogist 62: 403-410.

Hogarth, D. D., 1989. Pyrochlore, apatite and amphibole: distinctive minerals in carbonatite. In $\mathrm{K}$. Bell (Ed.) Carbonatites: genesis and evolution. London, Unwin Hyman, 105-148.

Krasnova, N.I., Petrov, T.G., Balaganskaya, E.G., Garcia, D., Moutte, D., Zaitsev, A.N. and Wall, F. 2004a. Introduction to phoscorites: occurrence, composition, nomenclature and petrogenesis. In: Phoscorites and Carbonatites from Mantle to Mine: the Key Example of the Kola Alkaline Province (F. Wall and A.N. Zaitsev, editors) Mineralogical Society Series, pp 45-79.
Le Bas, M. J., 1989. Diversification of carbonatite. In K. Bell, Ed., Carbonatites: genesis and evolution. London, Unwin Hyman, 428-447.

Lee, M.J., Garcia, D., Moutte, J., Lee, J.I., 2003. Phlogopite and tetraferriphlogopite from phoscorite and carbonatite associations in the Sokli massif, Northern Finland. Geosciences Journal 7: 9-20.

Lee, M.J., Garcia, D., Moutte, J., Williams, C.T. and Wall, F., 2004, Carbonatites and phoscorites from the Sokli complex, Finland. In: Phoscorites and Carbonatites from Mantle to Mine: the Key Example of the Kola Alkaline Province (F. Wall and A.N. Zaitsev, editors) Mineralogical Society Series. p. 133-162.

Lee, M. J., Lee, J. I., Moutte, J., 2005. Compositional variation of $\mathrm{Fe}-\mathrm{Ti}$ oxides from the Sokli complex, northeastern Finland. Geosciences Journal 9: 1-13.

Lumpkin, G.R., and Ewing, R.C., 1995. Geochemical alteration of pyrochlore group minerals: pyrochlore subgroup. American Mineralogist 80: 732-743.

Panina, L.I., Motorina, I.V., 2008. Liquid immiscibility in deep-seated magmas and the generation of carbonatite melts. Geochemistry International 46(5): 448-464.

Reguir, E.P., Chakhmouradian, A.R., Halden, N.M., Yang, P., Zaitsev, A.N., 2008. Early magmatic and reactioninduced trends in magnetite from the carbonatites of Kerimasi, Tanzania. Canadian Mineralogist 46: 879-900.

Taylor H.P., Frechen J., Degens E.T., 1967. Oxygen and carbon isotope studies of carbonatites from the Laacher See District, West Germany and the Alno District, Sweden. Geochimica et Cosmochimica Acta 31: 407-430.

Woolley A.R., Kempe D.R.C., 1989. Carbonatites: nomenclature, average chemical compositions, and element distribution. In K. Bell (Ed.) Carbonatites: genesis and evolution. London, Unwin Hyman, 1-14. 